\title{
Influence of Ambrosia artemisiifolia extract on germination and growth of Pisum sativum L. and Phaseolus vulgaris L. seedlings
}

Tanja Maksimović ${ }^{*}$, Larisa Marković ${ }^{1}$, Dino Hasanagić ${ }^{1}$

${ }^{1}$ University of Banja Luka, Faculty of Natural Sciences and Mathematics, Mladena Stojanovića 2, 78000 Banja

Luka, Republic of Srpska, Bosnia and Herzegovina

${ }^{*}$ Corresponding author: Tanja Maksimović, tanja.maksimovic@pmf.unibl.org

\begin{abstract}
Previous research has shown that there are allelopathic interactions between plants, releasing allelochemicals for which it is still unknown whether they are randomly generated or transmitted from generation to generation. In this paper, the influence dried ragweed leaves (Ambrosia artemisiifolia L.) aqueous extract of different concentrations: concentrated extract (10\%), extract diluted to 1/2 (5\%); 1/4 $(2.5 \%)$ and $1 / 8(1.25 \%)$ on germination and growth of peas and beans was monitored. The results showed that the increased concentration of ragweed extract inhibited germination, prolonged germination time and decreased the germination index of both test plant species compared to the control. The ragweed extract (concentrated and 1/2) reduced the growth of shoots and roots compared to the control (by more than 50\%), with the inhibitory effect being more visible on young pea plants compared to beans. The results of the research showed that the presence of ragweed as a weed in the field significantly reduces the germination and growth of cultivated plants, which is why care should be taken to suppress and remove it in a timely manner.
\end{abstract}

Keywords: Ambrosia artemisiifolia L., allelopathy, Pisum sativum L., Phaseolus vulgaris L., germination, aqueous extract

\section{Introduction}

Allelopathy is defined as a biological phenomenon that directly or indirectly, positively or negatively, affects plants through chemical substances called allelochemicals (Cheng and Cheng, 2015). Allelochemicals are present in almost all plants, their tissues, roots, stems, leaves, buds, flowers, pollen, fruits and seeds (Alam et al. 2001), which are released into the environment in certain amounts and under certain conditions acting on neighboring plants or cultivated crops causing phytotoxic effects (Novak et al. 2018). According to Aldrich and Kremer (1997) allelochemicals affect plant germination and growth by acting on various metabolic processes in plants, especially cell division and growth, growth regulators, mineral nutrition, photosynthesis, respiration, stoma opening, protein and fat synthesis, organic acid metabolism, membrane permeability and enzyme activity. Ragweed (Ambrosia artemisiifolia L.) as an invasive species which threatens the biological diversity of ecosystems by releasing some allelopathic compounds into the environment (phenolic and terpene compounds) and eliminating other species 
(Ramona, 2017). It also has a high allelopathic potential by inhibiting the germination and growth of competing plants, which puts it in a superior position (Sangeetha and Bashar, 2015).

The allelopathic effects of ragweed on other plants have not yet been sufficiently investigated (Buzhdygan and Bagley, 2016), although their inhibitory effect on crops has been documented in numerous studies (Choi et al., 2010; Lehoczky et al., 2011; Novak et al., 2018). Vidotto et al. (2013) found that ragweed extract inhibits the growth of tomatoes, lettuce and wheat, and stimulates the growth of barley. The research by Kincel et al. (2019) showed that different concentrations of Ambrosia artemisiifolia leaf extract stimulated root length and height of the corn plant by $30 \%$. Also, in this study, leaf extracts significantly reduced the germination of Amaranthus retroflexus seeds (2.22\% - 80\%). Further, Béres and Kazinczi (2000) found that an aqueous extract isolated from the leaves of Ambrosia artemisiifolia significantly inhibited seed germination and growth of primary crops of barley, corn, soybean and sunflower.

Given the fact that ragweed significantly inhibits the germination and growth of plants in crops, the aim of this study was to examine the allelopathic effect of different concentrations of ragweed aqueous extract on peas (Pisum sativum L.) and beans (Phaseolus vulgaris L.) seedlings.

\section{Material and Methods}

Aqueous extracts were prepared from dry plant leaves of Ambrosia artemisiifolia by a modified method of Lehoczky et al. (2011) and Majeed et al. (2012). The fresh plant leaves were first dried at room temperature over 10 days and then ground into a fine powder with the help of an electric grinder. The extract of dry plant parts was prepared in a ratio of 1:10 (100 g of plant mass in $1000 \mathrm{ml}$ of water- $10 \%$ plant mass: $90 \%$ water) and left at room temperature $\left(22^{\circ} \mathrm{C}\right)$ for $24 \mathrm{~h}$, after which the extract was filtered through quantitative filter paper. After $24 \mathrm{~h}$ that extracts has been used for preparing the following dilutions: $1 / 2$ (5\% extract), $1 / 4$ (2.5\% extract) and 1/8 (1.25\% extract). The allelopathic activity of ragweed was assessed by the biotesting method on pea (Pisum sativum L.) and bean (Phaseolus vulgaris L.) seeds. The seeds were surface sterilized with $1 \% \mathrm{NaOCl}$ for $5 \mathrm{~min}$, then 10 bean seeds and 15 peas were taken and placed in sterilized Petri dishes on wet filter paper. Petri dishes were incubated at $26^{\circ} \mathrm{C}$ for 7 days. Each treatment had 4 replicates, and both experiments were repeated twice.

The influence of different concentrations of aqueous ragweed extract on the germination percentage, mean germination time (MGT), seed germination rate (GI) and growth parameters (root and shoot length) were monitored after three, five and seven days.

Germination percentage was calculated by the following formula: 
Germination $\%=$ Number of germinated seeds/Total number of seeds at the beginning of the experiment $\times 100$.

Mean germination time (MGT) - calculated by the formula 1 (Elis and Roberts, 1981):

$$
\operatorname{MGT}=\Sigma(\mathrm{Dn}) / \Sigma \mathrm{n}
$$

where $\mathrm{n}$ is the number of seeds that germinated on day $\mathrm{D}$, and $\mathrm{D}$ is the number of days since germination began

Germination index (GI) -calculated according to the following formula (Khandakar and Bradbeer, (1983):

$$
\mathrm{GI}=\mathrm{n} 1 / \mathrm{d} 1+\mathrm{n} 2 / \mathrm{d} 2+\mathrm{n} 3 / \mathrm{d} 3+\mathrm{Nn} / \mathrm{n} \times 100
$$

where $\mathrm{n}=$ number of germinated seeds germinating $1,2,3 \ldots \mathrm{n}$-days after setting up the experiment, $\mathrm{d}=$ number of days

All data were statistically processed in the SPSS 20.0 program (Statistical Package for the Social Sciences). The analyses were performed in four independent replicates and the analyzed parameters were processed by the nonparametric Mann-Whitney $U$ test, at the significance level $p<0.05$.

\section{Results}

\section{Influence of aqueous ragweed extract on germination of pea and bean seeds}

The results of the research showed that the germination of peas varied in the range of $0-100 \%$ depending on the applied concentration and period. Concentrated ragweed leaf extract reduced pea germination by 80 $100 \%$ compared to the control. Pea seeds showed lower germination at an extract concentration of $1 / 2$ on the third day of monitoring, and on the fifth and seventh days germination was similar to that in the control. Extract concentrations of $1 / 4$ and 1/8 did not significantly inhibit pea seed germination (Figure 1A). Treatment with concentrated (10\%) ragweed aqueous extract significantly inhibited peas seed germination, as well as bean seed germination (reduced by 30-100\%) (Figure1A and 1B). 

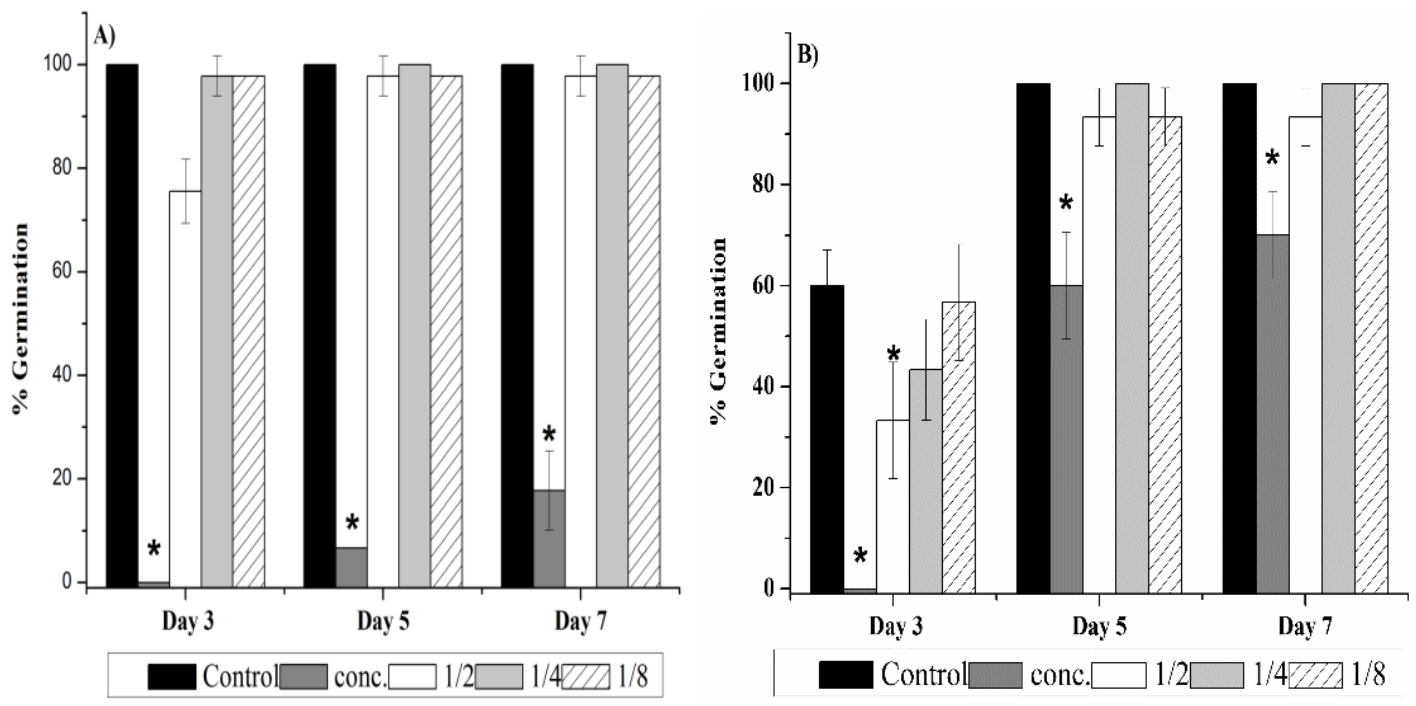

Figure 1. Germination (\%) of peas (A) and beans (B) treated with different concentrations of ragweed aqueous extract. The asterisk symbol indicates a statistically significant difference between control and treatment in the same period $(p<0.05)$.

\section{Influence of aqueous ragweed extract on average germination time and germination index of pea and bean seeds}

The results of the influence of aqueous ragweed extracts on average germination time (MGT) and germination index (GI) of pea and bean seeds are presented in Figure 2. In the control treatment MGT of peas was the fastest and was 5 days, while in the concentrated treatment (10\% extract) it was 6.5 day (Figure 2A). The results indicate that there is no significant statistical difference between the control and the applied extract concentration of $1 / 4$ and $1 / 8$ at the average MGT (Figure 2A). The average germination time of beans in the control was 5.31 days, and a similar germination time was found in the treatment of seeds with ragweed extract of $1 / 4$ and $1 / 8$ (Figure 2A). Treatments with concentrated ragweed extract extended the average germination time to 6.11 days.

The pea seed GI was higher compared to beans, with both GI being the highest in the appropriate control treatment. The GI of peas was maximal in the control (10.14) and at the lowest extracts concentration (1/4 and 1/8) and minimal at the highest extract concentration (0.58) (Figure 2B). The GI of bean seeds in the control treatment was the highest and amounted to 5.46 (Figure 2B), and the lowest in the concentrated extract. In both tested species, a significant statistical difference in germination rate between control and concentrated ragweed extract was found. 

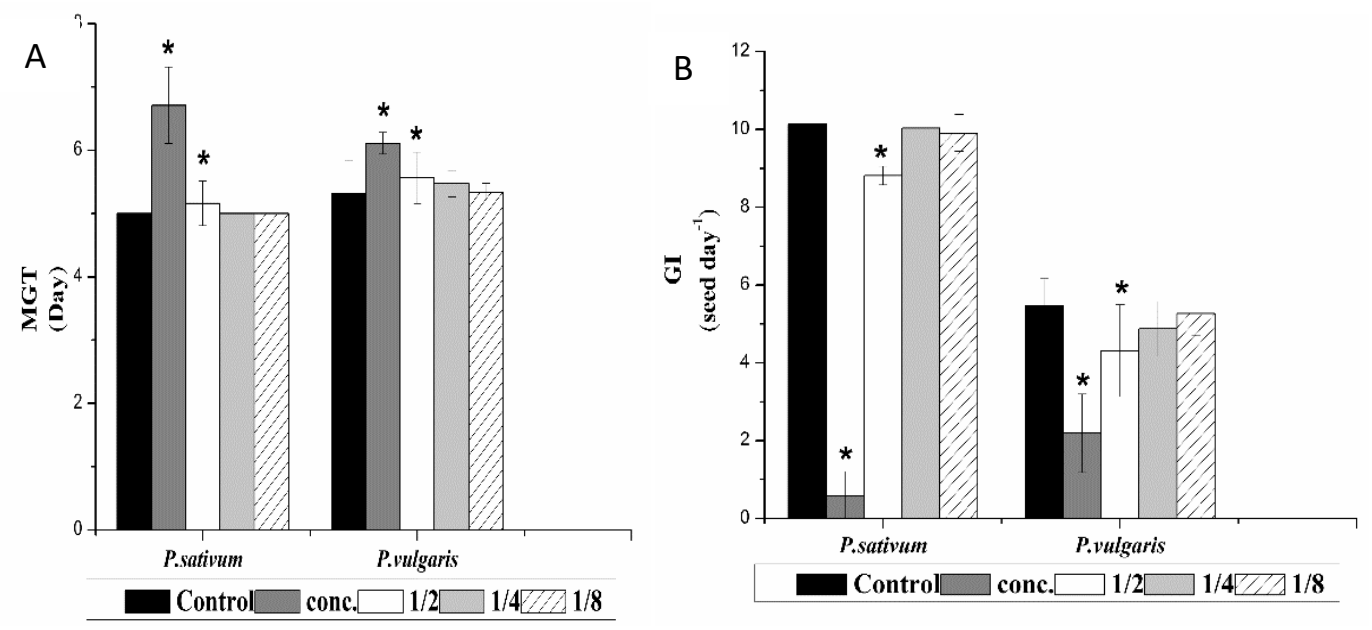

Figure 2. Mean germination time (MGT) (A) and germination index (GI) (B) of the tested species in control and at different concentrations of extracts. The asterisk symbol indicates a statistically significant difference between the control and the applied treatments in one examined species $(p<0.05)$.

\section{Influence of ragweed aqueous extract on the growth of pea and bean roots}

The applied concentrations of aqueous ragweed extract (concentrated extract, 1/2,1/4 and 1/8) significantly disrupted the growth parameters of peas and beans (Figure 3). In both tested plant species, there was a significant reduction in shoot growth compared to the root. In peas, the length of the roots was the largest in the control $(4.58 \mathrm{~cm})$, then at a concentration of $1 / 4$ and $1 / 8$, while in the concentrated extract it was significantly reduced $(0.66 \mathrm{~cm})$ (Figure $3 \mathrm{~A})$. A significant statistical difference was found between the control and all applied root treatments of both test plant species. The growth of pea shoots decreased in proportion to the increase of the extract concentration, so that in the concentrated extract there was a complete inhibition of shoots growth. A statistically significant difference was found between control and treatment (concentrated and dilution of the extract to $1 / 2$ ), while no statistically significant difference was found in the treatment of $1 / 4$ and $1 / 8$.

The length of the bean root in the control treatment was $5.23 \mathrm{~cm}$, while in the treatment with concentrated leaf extract no root growth was recorded. The ragweed extract caused a smaller effect on bean shoot and root length compared to peas. The highest value for shoots length was recorded in the control $(2.84 \mathrm{~cm})$ and the smallest in the concentrated extract $(2.36 \mathrm{~cm}$ ) (Figure 3B). A statistically significant difference was found between control and treatment (concentrated and dilution of the extract to 1/2), while no statistically significant difference was found in the treatment of $1 / 4$ and $1 / 8$. 

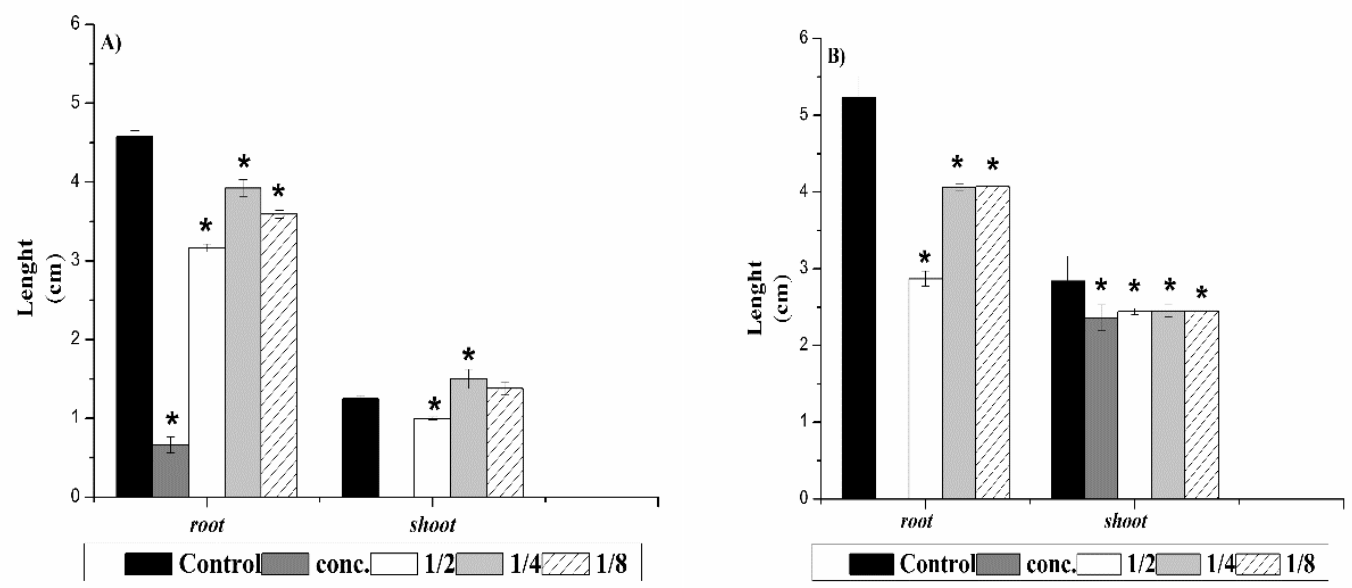

Figure 3. Influence of different concentrations of Ambrosia artemisiifolia extracts on root and shoot length of peas (A) and beans (B). The asterisk symbol indicates a statistically significant difference of the measured parameter between the control and the applied treatments in one examined species $(p<0.05)$.

\section{Discussion}

It is known that some plant species show tolerance to the presence of ragweed (Buzhdygan and Bagley, 2016), but mainly it has a negative impact on plants by slowing the germination and development of young plants (Béres and Kazinczi, 2000; Vidotto et al., 2013; Novak et al., 2018; Kincel et al., 2019). The results showed that the applied concentrations of aqueous ragweed extracts significantly affected the germination and initial growth of both examined plant species. Extracts of higher concentrations, especially concentrated and 1/2 reduced seed germination, germination index, prolonged germination time and led to poorer initial growth of young plants. Recent studies (Kincel et al., 2019) on the effect of ragweed extract on soybean, rice and maize seed germination have shown an inhibitory effect on both the growth and germination of the tested species depending on the applied concentration of the extract.

The inhibitory effect of aqueous ragweed extracts on germination was observed in all treatments, with germination being lower in peas compared to beans, and decreasing in the following order; concentrated extract $<1 / 2<1 / 4<1 / 8$. Higher concentrations of the extracts showed a strong inhibitory effect on both germination and growth of test species. Lehoczky et al. (2011) also reported a significant inhibitory effect of ragweed extracts on the germination of maize, wheat, rye and oats. Different results for wheat and barley in which germination is not inhibited by ragweed extracts were recorded by Buzhdygan and Bagley (2016). Differences in the effect on germination in ragweed extracts treatment can be attributed to different concentrations and different parts of the plant material used to prepare the extract, as well as the size and sensitivity of the seeds of the tested species (Novak et al., 2018). Concentrated ragweed extract prolonged 
MGT of peas more than beans. Extracts prepared from weed leaves of Chenopodium murale had a negative effect on the GI of wheat, corn, and beans (Islam et al., 2014).

The obtained results showed that the growth of seedlings of the tested species depended on the applied concentrations (concentrated, 1/2,1/4 and 1/8) of aqueous ragweed extracts. Csiszár (2009) noted that ragweed extracts inhibited maize germination and growth, while Lehoczky et al. (2011) found an inhibitory effect of ragweed extracts on the growth of wheat, rye and oats but not maize.

Wu et al. (2001) showed that aqueous extracts of ragweed in a concentration of $2.5 \%$ stimulate the elongation of wheat roots (Triticum aestivum L.), and concentrations of 5 to $10 \%$ inhibit it. Since the plants treated with ragweed extracts had a significantly shorter germination length than the root, it can be concluded that the ragweed had a significant inhibitory effect in the initial stages of growth on the shoot compared to the root. Vidotto et al. (2013) in their research noted that the growth of alfalfa, tomato and lettuce under the influence of ragweed extracts was inhibited by more than $50 \%$, while in wheat, barley and corn it was less reduced. In general, the effect of ragweed extracts had a greater effect on the growth of both types of shoots than on the growth of roots. This results in the fact that if peas and beans are found in the immediate vicinity of ragweed, it is very likely that growth will be endangered and later the yield will be reduced.

\section{Conclusion}

The results indicate a strong allelopathic activity of Ambrosia artemisiifolia L. extracts on germination and development of pea and bean seeds, where a lower percentage of germination in peas was found in comparison to beans. Aqueous extracts extended the average germination time and reduced the germination index of both test plant species. Lower root sensitivity in relation to seedlings shoot was demonstrated in both studied species. Given that ragweed develops near agricultural areas, its further uncontrolled spread could have a negative impact on the germination, growth and overall yield of different crops.

\section{References}

Alam SM, Ala S., Azmi AR, Khan MA, Ansari R. 2001: Allelopathy and its Role in Agriculture. Journal of Biological Sciences, 1(5): 308-315.

Aldrich RJ, Kremer RJ. 1997: Principles in Weed Management. Second Edition, Iowa State University Press, Ames.

Béres I, Kazinczi G. 2000: Allelopathic effects of shoot extracts and residues of weeds on field crops. Allelopathy Journal, 7: 93-98. 
Buzhdygan OY, Bagley OV. 2016: Developmental traits in grassland and agricultural plants under the influence of ragweed. Biological systems, 8 (2): 202-207.

Cheng F, Cheng Z. 2015: Research Progress on the use of Plant Allelopathy in Agriculture and the Physiological and Ecological Mechanisms of Allelopathy. Frontiers in Plant Science, 6:1020.

Choi BS, Song DY, Kim CG, Song BH, Woo SH, Lee CW. 2010: Allelopathic Effects of Common Ragweed (Ambrosia artemisifolia var. elatior) on the Germination and Seedling Growth of Crops and Weeds. Korean Journal of Weed Science, 30(1): 34-42.

Csiszár Á. 2009: Allelopathic effects of invasive woody plant species in Hungary. Acta Silvatica et Lignaria Hungarica, 5: 9-17.

Islam Irum-Us, Ahmed M, Asrar M, Siddiqui M F. 2014: Allelopathic effects of Chenopodium murale L. on four test species, Fuuast Journal of Biology, 4(1): 39-42

Khandakar A, Bradbeer JW. 1983: Jute seed quality. Bangladesh Journal of Agricultural Research. Council, Dhaka.

Kincel K, Ramona S, Alin C. 2019: Influence of Ambrosia artemisiifolia extract on germination and growth of Amaranthus retroflexus and Zea mays. Research Journal of Agricultural Science, 51 (2):127-135.

Lehoczky É, Gólya G, Szabó R, Szalai A. 2011: Allelopathic effects of ragweed (Ambrosia artemisiifolia L.) on cultivated plants. Communications in Agricultural and Applied Physiological Sciences, 76 (3): 545-9.

Novak N, Novak M, Bari, K, Šćepanović M, Ivić D. (2018): Allelopathic potential of segetal and ruderal invasive alien plants. Journal of Central European Agriculture, 19 (2): 389-403.

Ramona S. 2017: Chemical control of the invasive species Ambrosia artemisiifolia L. in sun flower agroecosystem, International Multidisciplinary Scientific GeoConference: SGEM: Surveying Geology \& mining Ecology Management, 17: 161-167.

Sangeetha C, Bashar P. 2015: Allelopathy in weed management: A critical review. African Journal of Agricultural Research, 10 (9): 1004-1015.

Vidotto F, Tesio F, Ferrero A, 2013: Allelopathic effects of Ambrosia artemisiifolia L. in the invasive process. Crop Protection, 54: 161-167.

Wu HW, Partley J, Lemerle D, Haig T. 2001: Allelopathy in wheat (Triticum aestivum). Annals of Applied Biology, 139: 1-9. 


\section{Uticaj ekstrakta Ambrosia artemisiifolia na klijanje i rast klijanaca Pisum sativum L. i Phaseolus vulgaris $\mathbf{L}$.}

Tanja Maksimović ${ }^{*}$, Larisa Marković ${ }^{1}$, Dino Hasanagić ${ }^{1}$

${ }^{1}$ University of Banja Luka, Faculty of Natural Sciences and Mathematics, Mladena Stojanovića 2, 78000 Banja Luka, Republic of Srpska, Bosnia and Herzegovina

*Corresponding author: Tanja Maksimović, tanja.maksimovic@pmf.unibl.org

\section{Izvod}

Dosadašnjim istraživanjima je utvrđeno da između biljaka postoje alelopatske interakcije pri čemu se oslobađaju alelohemikalije za koje se još uvijek ne zna da li se nasumično generišu ili se prenose iz generacije u generaciju. U ovom radu praćen je uticaj vodenog estrakta izolovanog iz suvih listova ambrozije (Ambrosia artemisiifolia L.) različitih koncentracija (koncentrovan ekstrakt, ekstrakt razblažen na $1 / 2 ; 1 / 4$ i 1/8) na klijavost i rast graška i pasulja. Rezultati istraživanja su pokazali da je povećana koncentracija ekstrakta ambrozije inhibirala klijavost, produžila vrijeme klijanja i smanjila indeks klijavosti obe testne biljne vrste u poređenju s kontrolom. Ekstrakt ambrozije (koncentrovan i 1/2) smanjio je rast ponika i korijena u poređenju s kontrolom (za više od 50\%), pri čemu je inhibitorni uticaj bio vidljiviji na mladim biljkama graška u odnosu na pasulj. Rezultati istraživanja su pokazli da prisustvo ambrozije kao korova u polju značajno redukuje rast gajenih biljaka zbog čega se treba voditi računa o pravovremenom suzbijanju i uklanjanju.

Ključne riječi: Ambrosia artemisiifolia L., allelopatija, Pisum sativum L., Phaseolus vulgaris L., klijavost, vodeni ekstrakt

Received 13.04.2021

Revised 04.09.2021

Accepted 04.10.2021 